\title{
STRATEGI KEPALA SEKOLAH DALAM MENINGKATKAN DISIPLIN KERJA GURU MAS 17 BAMBONG, KABUPATEN PIDIE
}

\section{PRINCIPAL STRATEGY TO IMPROVE WORK DISCIPLINE TEACHERS MAS 17 BAMBONG, PIDIE REGENCY}

\author{
Heri Fajri ${ }^{1}$ \\ ${ }^{1}$ Fakultas Keguruan dan Ilmu Pendidikan Universitas Jabal Ghafur \\ E-mail: herifajriunigha@gmail.com
}

Diterima: 13/11/2019; Disetujui: 28/11/2019

\begin{abstract}
ABSTRAK
Penelitian ini bertujuan untuk mendeskripsikan program kepala sekolah untuk meningkatkan disiplin kerja guru, kebijakan kepala sekolah untuk meningkatkan disiplin kerja guru, serta kendala kepala sekolah dalam meningkatkan disiplin kerja pada guru MAS 17 Bambong, Kabupaten Pidie. Penelitian ini menggunakan metode penelitian kualitatif dengan pendekatan deskriptif analisis. Teknik pengumpulan data yang digunakan adalah wawancara, observasi, dan studi dokumentasi. yang menjadi subjek penelitian yaitu kepala sekolah dan guru. Hasil penelitian menunjukkan bahwa program peningkatan disiplin kerja guru bersasaran untuk tercapainya proses pembelajaran dengan optimal, sehingga pada akhirnya mutu sekolah dapat diitingkatkan. Penyusunan program diarahkan agar proses pembelajaran berjalan dengan baik, efektif, dan menyenangkan, dan berorientasi kepada pencapaian tujuan sekolah. Kebijakan kepala sekolah untuk meningkatkan komitmen kedisiplinan guru dengan menerapkan kepemimpinan yang bersifat situasional bagi guru-guru yang komitmen kerjanya biasa, tetapi sikap mereka lebih patuh dalam melaksanakan tugasnya, kepala sekolah menerapkan kepemimpinan konsultatif dan partisipatif. Kepala sekolah selalu berdiskusi untuk mendapatkan cara yang disetujui oleh guru-guru. Kendala dalam meningkatkan disiplin kerja guru antara lain masih ada guru yang datang terlambat ke sekolah, masih ada guru yang tidak menyiapkan perangkat pembelajaran dengan lengkap, tidak menggunakan media dalam melaksanakan pembelajaran.
\end{abstract}

Kata kunci: Strategi, Kepala Sekolah, disiplin kerja, guru

\begin{abstract}
This study aimed to describe the principal program to improve labor discipline teachers, school principals policies to improve labor discipline of teachers, as well as the principal obstacle in improving labor discipline on teachers MAS 17 Bambong, Pidie regency. This study uses qualitative research with descriptive analysis approach. Data collection techniques used were interviews, observation and documentation. the subject of research that principals and teachers. The results showed that the labor discipline teacher improvement program targeted to achieve optimal learning process, which in turn can be diitingkatkan school quality. Programming directed to the learning process goes well, effective, and fun, and oriented to the achievement of the goals of the school. Policies principals to improve teacher discipline commitments by applying situational leadership for teachers who work
\end{abstract}


commitments outstanding, but they are more submissive attitude in carrying out its duties, the principal implementing consultative and participatory leadership. The headmaster always discuss ways to get approved by teachers. Constraints in improving labor discipline of teachers, among others, there are still teachers who arrive late to school, there are teachers who do not set up your device with full learning, do not use the media in implementing the learning. Policies principals to improve teacher discipline commitments by applying situational leadership for teachers who work commitments outstanding, but they are more submissive attitude in carrying out its duties, the principal implementing consultative and participatory leadership. The headmaster always discuss ways to get approved by teachers. Constraints in improving labor discipline of teachers, among others, there are still teachers who arrive late to school, there are teachers who do not set up your device with full learning, do not use the media in implementing the learning. Policies principals to improve teacher discipline commitments by applying situational leadership for teachers who work commitments outstanding, but they are more submissive attitude in carrying out its duties, the principal implementing consultative and participatory leadership. The headmaster always discuss ways to get approved by teachers. Constraints in improving labor discipline of teachers, among others, there are still teachers who arrive late to school, there are teachers who do not set up your device with full learning, do not use the media in implementing the learning. The headmaster always discuss ways to get approved by teachers. Constraints in improving labor discipline of teachers, among others, there are still teachers who arrive late to school, there are teachers who do not set up your device with full learning, do not use the media in implementing the learning. The headmaster always discuss ways to get approved by teachers. Constraints in improving labor discipline of teachers, among others, there are still teachers who arrive late to school, there are teachers who do not set up your device with full learning, do not use the media in implementing the learning.

Keywords: Strategy Principal, teachers work discipline

\section{PENDAHULUAN}

Mengajar perlu direncanakan dengan baik agar mencapai tujuan yang ditetapkan, pelaksanaannya harus ditunjang oleh kemampuan guru dalam menetapkan strategi yang efektif, hasilnya perlu dievaluasi secara obyektif. Di samping mengajar, salah satu masalah yang menuntut perhatian guru di sekolah adalah masalah disiplin kerja. Oleh karena itu, kemampuan profesional dan disiplin kerja seorang guru mempengaruhi pencapaian tujuan pendidikan. Disiplin kerja seorang guru mempunyai pengaruh besar terhadap pencapaian tujuan pendidikan pada suatu lembaga atau organisasi sekolah.

Disiplin sangat penting dan dibutuhkan setiap orang dalam melaksanakan pekerjaannya, karena motivasi adalah kondisi yang dapat menggerakkan guru agar mampu mencapai tujuan dari motivasinya. Motivasi kerja seseorang merupakan hal yang abstrak, tidak dapat dilihat tetapi dapat diamati dari perilaku 
orangnya. Oleh karena itu, kepala sekolah harus memiliki pengetahuan tentang motivasi.

Untuk mewujudkan disiplin tersebut sangat dipengaruhi oleh kemampuan kepala sekolah dalam mengelola setiap komponen sekolah, terutama berkaitan dengan pengetahuan dan pemahaman mereka terhadap manajemen dan kepemimpinan, serta tugas yang dibebankan kepadanya. Wahyudi (2009:63) menyatakan bahwa: "Kepala Sekolah yang efektif mempunyai karakreristik sebagai berikut: (1) mempunyai jiwa kepemimpinan dan mampu memimpin sekolah, (2) memiliki kemampuan untuk memecahkan masalah, (3) mempunyai keterampilan sosial, (4) profesional dan kompeten dalam bidang tugasnya."

Kepala Sekolah sebagai superleader harus bisa menjadi teman bagi peserta didiknya, rekan kerja yang menyenangkan bagi para guru, sejawat yang akrab bagi alumni, serta kompeten dalam manajemen dan kepemimpinan. Bahkan harus menjadi orator dan negosiator yang tangguh untuk menawarkan serta meyakinkan masyarakat dan orang tua mengenai programprogram sekolah agar mendapat dukungan penuh dalam implementasinya, hal tersebut sejalan dengan pendapat Mulyasa (2011:7) bahwa "Kepala sekolah adalah orang yang paling utama dalam memberikan motivasi kerja kepada guru, pegawai dan seluruh warga sekolah dalam mewujudkan tujuan pendidikan Nasional."
Berdasarkan pengamatan yang penulis lakukan pada MAS 17 Bambong, Kabupaten Pidie, ditemukan bahwa sebagian guru memiliki komitmen dan tanggung jawab dalam melaksanakan tugas pokok dan fungsinya, namun masih ada juga sebagian kecil guru yang kurang disiplin dan rendahnya motivasi dalam melakukan aktivitas. Realitas ini akan memberikan dampak terhadap tugas guru-guru terutama menyangkut disiplin dalam mengemban tugas.

Landasan utama yang mendasari suatu kebijakan adalah pertimbangan akal. Menurut Sudiyono (2007:3) bahwa: "Kebijakan (policy) seringkali dicampuradukkan dengan kebijaksanaan (wisdom)." Tentunya suatu kebijakan bukan semata-mata merupakan hasil pertimbangan akal manusia. Namun, akal manusia merupakan unsur yang dominan di dalam mengambil keputusan dari berbagai pilihan dalam pengambilan keputusan kebijakan. Sudiyono (2007:4) menyebutkan bahwa: "kebijakan adalah serangkaian tindakan yang memiliki tujuan yang diikuti oleh seseorang atau sekelompok pelaku terkait dengan suatu permasalahan tertentu."

Berdasarkan pengertian di atas, memberi pemaknaan bahwa kebijakan merupakan sebuah program yang diarahkan pada tujuan, nilai, dan praktik. Artinya kebijakan merupakan sebuah program yang disusun berdasarkan tujuan, termasuk nilai-nilai pembuat kebijakan dan 
fisibilitas dalam praktik. Dengan demikian, kebijakan mengandung unsur fisibilitas teknis, sosial, dan politik.

Kebijakan juga sering dipahami sebagai pedoman untuk bertindak untuk melakukan suatu aktivitas atau kegiatan. Pedoman tersebut bisa berwujud sederhana atau kompleks, bersifat umum ataupun khusus, luas ataupun sempit, kabur atau jelas, longgar atau terperinci, kualitatif atau kuantitatif, publik atau privat. Kebijakan dalam maknanya seperti ini mungkin berupa suatu deklarasi mengenai suatu dasar pedoman bertindak, suatu arah tindakan tertentu, suatu program mengenai aktivitasaktivitas atau suatu rencana yang telah diprogramkan.

Para ahli mengemukakan berbagai pendapat tentang kebijakan pendidikan. Tilaar (2009:7) menyatakan bahwa: "kebijakan pendidikan merupakan rumusan dari berbagai cara untuk mewujudkan tujuan pendidikan nasional. Pencapaian kedua pesan konstitusi untuk pendidikan nasional dijabarkan di dalam berbagai kebijakan pendidikan." Dengan demikian, kebijakan pendidikan harus sebangun dengan kebijakan publik di mana konteks kebijakan publik secara umum, yaitu kebijakan pembangunan, maka kebijakan merupakan bagian dari kebijakan publik. Kebijakan pendidikan dipahami sebagai kebijakan di bidang pendidikan, untuk mencapai tujuan pembangunan negara dan bangsa di bidang pendidikan, sebagai salah satu bagian dari tujuan pembangunan secara keseluruhan.

Di samping itu, Rohman (2009:108) menyatakan bahwa: "kebijakan pendidikan merupakan kebijakan publik yang mengatur khusus regulasi berkaitan dengan penyerapan sumber, alokasi dan distribusi sumber, serta pengaturan perilaku dalam pendidikan." Kebijakan pendidikan adalah keseluruhan dari proses dan hasil perumusan langkah-langkah strategis pendidikan yang dijabarkan dari visi, misi pendidikan dalam rangka untuk mewujudkan tercapainya tujuan pendidikan dalam suatu masyarakat untuk kurun waktu tertentu.

Rumusan kebijakan pendidikan dapat dihasilkan dengan baik, apabila mempertimbangkan beberapa kriteria, seperti adanya tujuan yang ingin dicapai serta adanya program yang jelas. Hal ini, sebagaimana dijelaskan oleh Rohman (2009:119) antara lain:

1) suatu kebijakan pendidikan yang hendak diwujudkan harus memiliki tujuan (goal) yang jelas sebagaimana diinginkan. 2) tujuan yang diinginkan itu harus pula direncanakan (plans) atau harus ada proposal secara matang, yakni pengertian yang spesifik dan operasional untuk mencapai tujuan. 3) harus ada (program), yaitu upaya dan cara-cara dari yang berwenang untuk mencapai tujuan. 4) adalah (decision), yaitu segenap tindakan untuk menentukan tujuan, membuat rencana, melaksanakan dan mengevaluasi program. 5) adalah (efect), yaitu akibatakibat dari program yang akan dijalankan baik yang diinginkan atau 
disengaja maupun tidak disengaja, baik yang primer maupun sekunder.

Merujuk kepada berbagai pendapat di atas, kebijakan pendidikan merupakan hasil dari keputusan yang diambil dengan mempertimbangkan kaitan pendidikan dengan komponen sosial yang lain. Oleh karena itu, seperti halnya analisis kebijakan dalam bidang lain, sifat kontekstual dan interdisipliner ini merupakan ciri analisis kebijakan pendidikan.

Kepemimpinan pada semua jenjang pendidikan formal, memerlukan pengalaman dan keterampilan yang memadai agar sasaran, tujuan, maupun target pendidikan di suatu sekolah tercapai dengan baik. Murniati (2008:125) menyatakan bahwa: "Kompleksnya penguasaan keterampilan yang harus dimiliki seorang pemimpin menunjukkan bahwa pekerjaan memimpin bukanlah suatu pekerjaan yang mudah."

Sebelum diuraikan secara mendalam tentang kepemimpinan lembaga pendidikan sekolah dalam melaksanakan tugas dan fungsinya, terlebih dahulu perlu dijelaskan makna kepemimpinan dari konsep manajemen pendidikan. Hal ini perlu diketengahkan karena tidak terdapat perbedaan secara essensial tentang rumusan pengertian yang dikemukakan oleh para teoretisi.

Kepemimpinan menurut para pakar muncul ketika manusia mulai membentuk organisasi atau kelompok-kelompok sebagai kebutuhan dasarnya untuk bekerjasama dalam mencapai tujuan. Ketika manusia membentuk kelompok atau organisasi, maka harus ada salah seorang yang ditunjuk atau dipilih sebagai pemimpin yang akan mewakili kelompok dalam penyelesaian masalah. Untuk memahami konsep kepemimpinan, khususnya kepemimpinan pendidikan perlu dikaji secara lebih mendalam.

Kepemimpinan artinya kemampuan mempengaruhi orang-orang agar mereka bersedia bekerja sesuai dengan keinginan pemimpin. Hal ini dapat dikatakan sebagai suatu kekuatan untuk mengatur dan mengelola suatu organisasi baik organisasi atau kelompok dalam masyarakat. Kepemimpinan merupakan salah satu fungsi manajemen yang merupakan hal penting untuk mencapai tujuan dalam suatu organisasi. Muhaimin, Suti'ah dan Prabowo (2010:29) menguraikan, sebagai berikut:

Kepemimpinan merupakan salah satu faktor yang sangat berperan dalam organisasi, baik buruknya organisasi sering kali sebagian besar tergantung pada faktor pemimpin. Berbagai riset telah membuktikan bahwa faktor pemimpin memegang peranan penting dalam pengembangan organisasi. Faktor pemimpin yang sangat penting adalah karakter dari orang yang menjadi pemimpin tersebut. Bahwa 90 persen dari semua kegagalan kepemimpinan adalah kegagalan pada karakter.

Berdasarkan kutipan di atas, memberi kejelasan bahwa kepemimpinan juga dapat dijadikan alat untuk menyelesaikan masalahmasalah yang terjadi dalam suatu organisasi. Secara jelas dapat dikatakan bahwa munculnya kepemimpinan adalah ketika masyarakat mulai 
menjalin kerjasama antara dua orang atau lebih untuk mencapai tujuan yang telah ditetapkan. Kepemimpinan berperan dalam melindungi dan mengatur semua kegiatan dalam organisasi; seperti menyusun struktur, merancang program, dan merealisasikan program dalam suatu organisasi baik dalam skala kecil maupun besar.

Sebagaimana telah ditegaskan bahwa di mana ada kelompok manusia atau organisasi, maka harus ada seseorang yang dipercaya sebagai pemimpin. Pemimpin sebagai manusia tentu mempunyai sifat, kebiasaan, temperamen, watak dan kepribadian yang unik dan khas, sehingga tingkah laku dan gaya yang dimiliki inilah yang membedakannya dengan orang lain.

Sudah tentu gaya hidupnya yang dipancarkan dari komponen kepribadiannya, selalu mewarnai perilaku dan pola bertindak dalam mengambil keputusan dan inilah yang disebut dengan tipe kepemimpinannya. Jadi gaya kepemimpinan seorang pimpinan lembaga tidak lepas dari tipe kepribadiannya dan hal ini dapat dijumpai dalam kehidupan sehari-hari baik dalam organisasi atau /lembaga pendidikan formal maupun informal.

Gaya kepemimpinan yang ditampilkan oleh seseorang adalah cerminan dari sifat dan kepribadian seorang pemimpin. Istilah gaya (style) kepemimpinan merupakan norma perilaku yang digunakan oleh seseorang pada saat ia mempengaruhi perilaku orang lain. Thoha (2008:257) menyatakan bahwa: "Di satu pihak manusia terbatas kemampuannya untuk mempimpin, di pihak lain ada orang yang mempunyai kelebihan kemampuan untuk memimpin. Di sinilah timbulmnya kebutuhan akan pemimpin dan kepemimpinan."

Gaya kepemimpinan seseorang tidak sama antara satu dengan lainnya. Semua ini dilatar belakangi oleh berbagai faktor, baik pendidikan, pengalaman, lingkungan, maupun karakter dari pemimpin itu sendiri. Gaya kepemimpinan adalah cara pemimpin dalam menghadapi dan melayani staf atau bawahan yang biasanya berbeda pada setiap individu dan dapat berubah-ubah. Thoha (2008:303) menyatakan bahwa: "Istilah gaya secara kasar adalah sama dengan cara yang dipergunakan pemimpin di dalam mempengaruhi para pengikutnya." Artinya seseorang yang menduduki jabatan pimpinan hendaknya mempunyai kearifan dalam "membaca" situasi yang dihadapinya secara tepat dan menyesuaikan gaya kepemimpinan yang akan digunakan dengan tuntutan situasi, meskipun penyesuaian ini hanya bersifat sementara.

Gaya bersikap dan bertindak seseorang pemimpin akan tampak dari cara ia memberi perintah, berkomunikasi, dan memotivasi bawahannya. Hal ini sebagaimana dijelaskan oleh Sutrisno (2011:222) sebagai berikut:

Gaya bersikap dan bertindak akan tampak dari: cara memberi perintah, cara memberi tugas, cara berkomunikasi, cara membuat keputusan, cara mendorong 
semangat bawahan, cara memberi bimbingan, cara menegakkan disiplin, cara mengawasi pekerjaan bawahan, cara meminta laporan dari bawahan, cara memimpin rapat, cara menegur kesalahan bawahan, dan lain-lain.

Kepemimpinan pendidikan adalah posisi yang sangat menuntut kemampuan membaca dan memahami karakter, sifat-sifat dan kepribadian pegawai yang menjadi bawahannya. Karena pegawai yang akan dipimpin oleh pimpinan lembaga tentu mempunyai perilaku dan kepribadian yang berbeda-beda, maka untuk dapat membina mereka, pimpinan harus dapat menyesuaikan gaya kepemimpinan yang akan digunakan dengan kondisi dan situasi bawahannya.

Gaya kepemimpinan pendidikan adalah cara seseorang pimpinan lembaga pendidikan dalam mengatur, mengarahkan, dan membimbing bawahan agar mereka bekerjasama untuk mencapai tujuan pendidikan dengan efektif. Berkenaan dengan gaya kepemimpinan, Fattah (2009:93) mengatakan bahwa: "berbagai gaya atau perilaku pemimpin berfokus pada dua gaya dasar yaitu gaya yang berorientasi pada tugas atau "concern for job description" dan gaya yang berorientasi pada hubungan dengan bawahan atau "concern for people."

Jadi pada setiap lembaga/organisasi, pada umumnya gaya kepemimpinan yang digunakan atau dimunculkan oleh pemimpin berbeda karena orientasi gaya itu sendiri berbeda. Seseorang menjadi pemimpin bukan hanya karena faktor kepribadian yang dimilikinya, akan tetapi faktor situasipun ikut mempengaruhi. Antara pemimpin dan situasi terdapat hubungan yang erat karena pemimpin dikatakan berhasil bila ia dapat menerapkan gaya kepemimpinan yang tepat pada situasi yang tepat pula.

Kepala sekolah sebenarnya adalah tenaga fungsional sekolah yang diberi tugas untuk memimpin penyelenggaran sekolah. Oleh karena itu komposisinya dititikberatkan pada tugas-tugas kepala sekolah bukan pada posisi proses belajar mengajar.

Kemampuan kepala sekolah untuk menganalisis persoalan, memberikan berbagai pertimbangan, kecakapan berorganisasi, kemampuan berkomunikasi secara lisan maupun secara tertulis, keinginan untuk berpartisipasi dan kecakapan dalam mendiskusikan hal-hal yang aktual, motivasi memahami bawahan. Latar belakang filosofis pendidikan kepala sekolah menurut Arifin (2007: 89) adalah:

1. Kepala sekolah adalah pemimpin yang mempunyai peranan yang sangat penting dalam meningkatkan mutu pendidikan sekolah.

2. Kepala sekolah harus senantiasa meningkatkan kemampuan pengabdian dan kreativitas agar dapat melaksanakan tugas-tugas secara profesional.

Kepala sekolah dalam paradigma 
manajemen pendidikan baru akan memberikan dampak positif dan perubahan yang cukup mendasar dalam pembaharuan sistem pendidikan di sekolahnya. Dampak tersebut antara lain terhadap efektivitas pendidikan, kepemimpinan sekolah yang kuat, pengelolaan tenaga kependidikan yang efektif, budaya mutu, team work yang kompak, cerdas dan dinamis, kemandirian, partisipasi warga sekolah dan masyarakat, keterbukaan, (transparansi) kemauan untuk berubah (psikologis dan fisik), evaluasi dan perbaikan berkelanjutan (kontinu), responsif dan antisipatif terhadap kebutuhan dan akuntabilitas.

Kualitas kepala sekolah yang dimaksud adalah kepala sekolah yang benarbenar memiliki latar belakang pendidikan dan pengalaman yang cukup mengenai masalahmasalah yang dihadapi oleh pendidikan di sekolah tersebut. Pengalaman dan manajerial kepemimpinan sangat penting dimiliki, karena indikator tersebut ikut mempengaruhi lembaga yang dipimpinnya. Kemudian kepala sekolah yang dapat mengelola sumber daya pendidikan yang ada dilembaga pendidikan tersebut agar benar-benar berfungsi sebagai peningkatan mutu pendidikan yang dikelolanya.

Kualitas kepala sekolah yang diharapkan oleh para bawahan, paling tidak ada lima karakteristik yang harus dipenuhi, menurut Danim (2007:6) di antaranya:

1. Bawahan menginginkan agar kepala sekolah mempunyai tujuan yang jelas dan konsisten, dengan harapan tidak mudah terbawa kepada arus angin, melainkan melaksanakan tugas sesuai dengan harapan pemerintah dan kebutuhan sekolah baik kualitas maupun kuantitas.

2. Bawahan menginginkan kepala sekolah membuat rencana yang baik dan dapat dijangkau oleh para guru dan anak didik.

3. Bawahan menginginkan kepala sekolah yang secara terus menerus menginformasikan kemajuan kepada bawahan.

Keberhasilan atau kegagalan seorang kepala sekolah tidak hanya ditentukan oleh dirinya sendiri, akan tetapi juga ditentukan oleh akumulasi subsistem yang terlibat, yaitu kepala sekolah sendiri dengan seperangkat potensinya, karakteristik bawahan, karakteristik situasi, kondisi, organisasi di luar manusianya, dan karakteristik situasi dan kondisi di luar sekolah. Keberhasilan sekolah mengandung arti keberhasilan pemimpin sekolah. Untuk menunjang kemampuan kepala sekolah di samping kemampuan akademik juga perlu adanya penambahan yang berasal dari luar akademik seperti pelatihan, workshop, dan seminar.

\section{METODE PENELITIAN}

Penelitian ini menggunakan metode kualitatif dengan deskriptif analisis. Hal ini sejalan dengan pendapat Sugiyono (2011:11) bahwa: "Penelitian deskriptif adalah penelitian yang dilakukan untuk mengetahui nilai variabel mandiri, baik satu variabel atau lebih 
(independen) tanpa membuat perbandingan, atau menghubungkan antara variabel yang satu dengan variabel yang lain."

Peneliti memusatkan diri pada persoalan-persoalan aktual melalui pengumpulan data dan analisis data lapangan. Dengan menggunakan pendekatan ini, peneliti mengharapkan dapat menghasilkan data deskriptif berupa tulisan atau lisan dari sumber data yang perlu diamati.

Adapun Lokasi penelitian pada MAS 17 Bambong, Kabupaten Pidie, yang menjadi subjek penelitian ini adalah Kepala Sekolah dan Guru pada MAS 17 Bambong, Kabupaten Pidie. Penentuan responden dalam penelitian ini dilakukan dengan purposive sampling, artinya sampel yang diteliti terlebih dahulu dipilih secara purposive. Dalam kaitannya dengan sumber data ini, Sugiyono (2011:91) menyatakan: "sampel adalah bagian dari jumlah dan karakteristik yang dimiliki oleh populasi tersebut."

Instrumen yang digunakan untuk mengumpulkan data mengenai strategi kepala sekolah meningkatkan disiplin kerja guru adalah pedoman wawancara, pedoman observasi dan studi dokumentasi dengan mengajukan pertanyaan-pertanyaan yang telah dirumuskan sesuai dengan tujuan penelitian untuk memperoleh jawaban yang dijadikan sebagai hasil data kualitatif yang dapat dipertanggung jawabkan keabsahan dan kebenarannya.

\section{HASIL PENELITIAN DAN PEMBAHASAN} Program Kepala Sekolah dalam

\section{Meningkatkan Disiplin Kerja Guru}

Hasil penelitian menunjukkan bahwa program peningkatan disiplin dan motivasi kerja guru bersasaran untuk tercapainya proses pembelajaran dengan optimal, sehingga pada akhirnya mutu sekolah dapat ditingkatkan. Setiap penyusunan program diarahkan agar proses pembelajaran berjalan dengan baik, efektif, dan menyenangkan, dan berorientasi kepada pencapaian tujuan sekolah. Hal ini dapat dilakukan dengan mendorong guru-guru untuk menerapkan strategi pembelajaran yang sesuai dan baik sehingga mutu sekolah dapat ditingkatkan. Sanjaya (2009:196-197) menguraikan sebagai berikut:

Mengapa pembelajaran dikatakan
sebagai suatu sistem? Karena
pembelajaran adalah kegiatan yang
bertujuan, yaitu membelajarkan siswa.
Proses pembelajaran itu merupakan
rangkaian kegiatan yang melibatkan
berbagai komponen. Itulah pentingnya
setiap guru memahami sistem
pembelajaran. Melalui pemahaman
sistem, minimal setiap guru akan
memahami tentang tujuan pembelajaran
atau hasil yang diharapkan, proses
pembelajaran yang harus dilakukan,
pemanfaatan setiap komponen dalam
proses kegiatan untuk mencapai tujuan
serta bagaimana mengetahui
keberhasilan pencapaian tersebut.
Proses pembelajaran merupakan bagian
yang tidak terpisahkan dengan program sekolah dan kurikulum itu sendiri. Disadari bahwa 
pembelajaran yang baik, juga akan menentukan keberhasilan implementasi program pada suatu lembaga pendidikan. Pelaksanaan kurikulum di sekolah melalui empat tahap, yaitu:

perencanaan, (2) pengorganisasian dan koordinasi, (3) pelakasanaan, dan (4) pengendalian.

Tahap perencanaan, pada tahap ini kurikulum dijabarkan sampai menjadi rencana pengajaran, maka untuk itu guru pengajaran melakukan beberapa kegiatan, seperti menjabarkan program pembelajaran, menelaah berdasarkan kalender pendidikan, menyusun program satuan pelajaran, menyusun rencana pengajaran. Berdasarkan hasil penelitian menunujukkan bahwa penyusunan mata pelajaran sampai dengan rencana pembelajaran tidak dikerjakan seorang diri oleh guru.

Tahap pengorganisasian, pada tahap ini, kepala sekolah bersama pengajaran mengatur pembagian tugas mengajar dan tugas-tugas lain dilakukan oleh kepala sekolah secara merata, sesuai dengan bidang keahlian dan permintaan guru, penyusunan jadwal pelajaran, penyusunan jadwal kegiatan perbaikan dan pengayaan, penyusunan jadwal penyegaran guru dengan sasaran agar guru-guru secara periodik mendapatkan penyegaran tentang perkembangan ilmu pengetahuan dan teknologi, strategi pembelajaran, dan metode mengajar. Berkenaan tentang pentingnya guru-guru memahami strategi pembelajaran, dijelaskan oleh Gulo (2008:3-4) sebagai berikut:

Strategi belajar mengajar merupakan rancangan dasar bagi seorang guru tentang cara ia membawakan pengajarannya di kelas secara bertanggung jawab. Strategi instruksional tidak sama dengan desain instruksional. Desain instruksional merupakan blue print suatu pengajaran. Blue print itu baru dapat disusun setelah ditetapkan model dan bentuk pengajaran yang dikehendaki.

Tahap pengendalian, pada tahap ini aspek yang diperhatikan oleh kepala sekolah, anatar lain: (a) jenis evaluasi dikaitkan dengan tujuannya, dan (b) pemanfaatan hasil evaluasi. Pada bagian ini kepala sekolah mengingatkan guru-gurunya bahwa evaluasi memiliki tujuan ganda, yaitu untuk mengetahui ketercapaian tujuan pembelajaran dan mengetahui kesulitan siswa. Untuk mengetahui ketercapaian tujuan pembelajaran guru dapat menggunakan berbagai alat penilaian yang sesuai, sedangkan untuk mengetahui kesulitan siswa menggunakan tes diagnostik, semua proses ini bersasaran untuk tercapainya implementasi kurikulum dengan optimal.

\section{Kebijakan Kepala Sekolah dalam Meningkatkan Komitmen Terhadap Disiplin Kerja Guru}

Berdasarkan hasil penelitian, gaya kepemimpinan kepala sekolah dalam meningkatkan komitmen guru adalah dengan menerapkan gaya kepemimpinan demokratis dengan bersikap adil terhadap seluruh stafnya, dan memperhatikan stafnya dengan sama rata 
dan bersikap adil dalam pembagian tugas maupun dalam pembagian kesejahteraan yang berpedoman pada beban tugas yang dialami.

Kepala Sekolah sebagai pimpinan sekaligus manajer di sekolah harus bersikap adil kepada stafnya, menaruh perhatian yang sama kepada stafnya, bersikap ramah, dan memberikan tugas kepada guru serta harus memperhatikan kemampuan individual guru dalam penelitian. Hasil penelitian diketahui bahwa kepala sekolah memberikan bimbingan dan teguran kepada guru yang belum menjalankan tugasnya dengan baik. Di samping itu, memberikan penghargaan dan apresiasi kepada guru yang berdisiplin, memiliki motivasi tinggi, dan berprestasi baik. Berkenaan dengan indikator karakteristik penghargaan terhadap guru, dijelaskan oleh Mulyasa (2011:78) sebagai berikut:

Terdapat prosedur pemberian penghargaan dan insentifg terhadap guru, staf, dan peserta didik yang berprestasi, sehingga prestasi yang tinggi dari peserta didik dan guru mendapatkan penghargaan dari sekolah. Dinas Pendidikan Kabupaten/Kota mengambil peran nyata dalam pemberian penghargaan atas prestasi peserta didik yang hebat.

Hasil penelitian bahwa apabila kepala sekolah menginstruksikan kepada guru untuk hadir pada pukul 7 pagi setiap hari Senin, mereka menjalankannya sesuai dengan instruksi kepala sekolah, karena kepala sekolah dalam memimpin MAS 17 Bambong, Kabupaten Pidie selalu bersikap adil baik dalam pemberian tugas maupun dalam pembagian kesejahteraan yang berpedoman kepada beban tugas yang diemban guru. Kepala sekolah menganggap guru sebagai mitra kerja yang selalu dapat diajak bertukar pikiran dan dapat berkomunikasi di manapun berada tidak harus di ruang kepala sekolah. Hal ini mencerminkan bahwa kepala sekolah yang berjiwa besar dan rendah hati tidak menganggap jabatan sebagai sesuatu yang dapat dibanggakan melainkan sebagai amanah yang harus diemban, dikelola dan dipertanggung jawabkan baik kepada manusia maupun kepada Allah SWT.

Salah satu faktor lain yang mempengaruhi komitmen kerja guru adalah faktor kenyamanan dan keamanan (security) dalam bekerja. Hasil penelitian menunjukkan bahwa gaya kepemimpinan kepala sekolah dalam upaya meningkatkan komitmen kerja guru adalah dengan gaya kepemimpinan partisipatif dan konsultatif untuk mengupayakan tersedianya semua sarana dan media yang dibutuhkan oleh guru. Artinya, kepala sekolah selalu mendiskusikan kebutuhan guru dalam melaksanakan proses pembelajaran terutama buku paket dan media lainnya.

Berdasarkan uraian hasil penelitian dan dikaitkan dengan pendapat para ahli dapat disebutkan bahwa kepala sekolah telah menerapkan kepemimpinan dengan pola keteladanan untuk meningkatkan disiplin kerja guru.

\footnotetext{
Kendala Kepala Sekolah dalam Meningkatkan Disiplin Kerja Guru
} 
Hasil penelitian menunjukkan bahwa dalam menjalankan lembaga pendidikan, kepala sekolah dituntut untuk memiliki berbagai macam teknik dan strategi untuk dapat mencapai keberhasilan. Gaya yang digunakan oleh kepala sekolah dalam meningkatkan disiplin kerja guru, kepala sekolah menganggap guru sebagai mitra dalam mensukseskan program sekolah. Dalam hal ini kepala sekolah berusaha untuk memotivasi guru dengan menetapkan standar kerja yang tinggi yang berbasis pada peningkatan mutu.

Dalam upaya mewujudkan terciptanya kedisiplinan yang tinggi masih ditemui beberapa kendala. Khusus dalam hal kunjungan ke sekolah lain Khusus dalam hal kunjungan ke sekolah lain (studi banding), kendalanya sulit menentukan jadwal kunjungan. Sehingga kadang-kadang kegiatan yang telah diprogramkan tidak bisa dilaksanakan secara optimal oleh guru-guru dengan tepat waktu.

Hasil penelitian terungkap bahwa kepala sekolah dalam menjalankan tugasnya sangat menentukan keberhasilan sekolah tersebut dalam melahirkan out-put yang berkompeten dengan bentuk kepemimpinan yang dapat memacu motivasi dalam bekerja. Untuk seorang pemimpinm perlu selalu meningkatkan motivasi bawahan. Fachrudi (2007:17) menyatakan: "Kemampuan terpimpin berunsur pada kemampuan pengetahuan dan kemampuan keterampilan dalam memberikan motivasi terhadap bawahannya."

Kendala yang ditemui bahwa masih ada sebagian kecil guru yang datang terlambat, sehingga ketika proses pembelajaran sudah berjalan lebih kurang 10 menit, mereka baru datang. Kondisi ini dapat menyebabkan rendahnya motivasi guru lain untuk hadir ke sekolah tepat waktu. Kurang motivasinya dalam belajar. Realitas ini sebagaimana diungkapkan oleh Gulo (2008:22) bahwa:

Guru sebagai penolong berusaha memberi bantuan kepada peserta didik untuk mengembangkan dirinya secara utuh berdasarkan kasih sayang yang membarui. Guru berdiri di anatara peserta didik dan Tuhan yang memberinya tanggung jawab yang telah dan terus-menerus dikuasainya beserta dengan seluruh pengalamannya mengantarkan peserta didik ke arah pengenalan akan ciptaan Tuhan dengan segala hukum-hukum-Nya.

Berdasarkan kutipan di atas, memberi kejelasan pentingnya kedisplinan guru dalam melaksanakan tugas, karena hal tersebut ikut mempengaruhi keberhasilan anak didiknya dalam kegiatan pembelajaran. Begitu juga halnya kasih sayang dan perhatian guru terhadap siswanya ikut mempengaruhi aktivitas pembelajaran yang dikutinya. 
Kendala lain yang masih ditemui kepala sekolah dalam meningkatkan disiplin kerja guru adalah masih ada guru yang tidak menyiapkan perangkat pembelajaran dengan lengkap, tidak pernah menggunakan media dalam melaksanakan pembelajaran. Begitu juga halnya dengan kegiatan evaluasi, masih ada guru tidak melakukan secara kontinu, sehingga apa yang tertulis dalam perangkat pembelajaran (RPP) tidak dijabarkan dan dilaksanakan dengan baik.

\section{SIMPULAN}

1. Program peningkatan disiplin kerja guru bersasaran untuk tercapainya proses pembelajaran dengan optimal, sehingga pada akhirnya mutu sekolah dapat ditingkatkan. Setiap penyusunan program diarahkan agar proses pembelajaran berjalan dengan baik, efektif, dan menyenangkan, dan berorientasi kepada pencapaian tujuan sekolah.

2. Kebijakan kepala sekolah untuk meningkatkan komitmen guru terhadap disiplin kerja guru dengan menerapkan gaya kepemimpinan yang bersifat situasional bagi guru-guru yang komitmen kerjanya biasa, tetapi sikap mereka lebih patuh dalam melaksanakan tugasnya, kepala sekolah menerapkan kepemimpinan konsultatif dan partisipatif. Dalam meningkatkan komitmen guru, kepala sekolah banyak berdiskusi untuk mendapatkan cara yang disetujui oleh guru-guru. Sebaliknya terhadap guru-guru yang berkomitmen rendah dan berwatak sukar diperintah, kepala sekolah menganut kepemimpinan instruktif atau otoriter.

3. Kendala kepala sekolah dalam meningkatkan disiplin kerja guru antara lain masih ada sebagian kecil guru yang datang terlambat, sehingga ketika proses pembelajaran sudah berjalan lebih kurang 10 menit, mereka baru datang. Masih ada guru yang tidak menyiapkan perangkat pembelajaran dengan lengkap, tidak pernah menggunakan media dalam melaksanakan pembelajaran. Begitu juga halnya dengan kegiatan evaluasi, masih ada guru tidak melakukan secara kontinu, sehingga apa yang tertulis dalam perangkat pembelajaran (RPP) tidak dijabarkan dan dilaksanakan dengan baik. 


\section{DAFTAR PUSTAKA}

Arifin, R. (2007). Peran Kepemimpinan Sekolah yang Efektif. Jakarta: Jurnal Manajemen Pendidikan.

Danim, Sudarwan. (2007). Motivasi, Kepemimpinan dan Efektivitas Kelompok. Jakarta: Rineka Cipta.

Fattah, Nanang. (2009). Landasan Manajemen Pendidikan. Bandung: Remaja Rosdakarya.

Gulo, W. (2008). Strategi Belajar Mengajar. Jakarta: Grasindo.

Indrafachrudi. (2007). Mengantar Bagaimana Memimpin Sekolah yang Baik. Jakarta: Raja Grafindo Persada.

Mulyasa. E. (2007). Manajemen Berbasis Sekolah. Bandung: Remaja Rosdakarya. (2011). Manajemen Kepemimpinan Kepala Sekolah. Jakarta: Bumi Aksara.

Murniati A.R. (2008). Manajemen Stratejik Peran Kepala Sekolah dalam Pemberdayaan. Bandung: Citapustaka Media Perintis.

Sanjaya, Wina (2009). Kurikulum dan Pembelajaran: Teori dan Praktik Pengembangan Kurikulum Tigkat Satuan Pendidikan (KTSP). Jakarta: Kencana.

Sugiyono. (2011). Memahami Penelitian Kualitatif. Bandung: Alfabeta.

Thoha, Miftah. (2008). Perilaku Organisasi Konsep Dasar dan Aplikasinya. Jakarta: Raja Grafindo Persada.

Tilaar, H.A.R. (2009). Kekuasaan dan Pendidikan, Manajemen Pendidikan Nasional dalam Pusaran Kekuasaan. Jakarta: Rineka Cipta.

Wahyudi. (2009). Kepemimpinan Kepala Sekolah dalam Organisasi Pembelajaran. Bandung: Alfabeta. 